\title{
PENGARUH TERAPI BEKAM KERING TERHADAP TEKANAN DARAH PADA LANSIA DENGAN HIPERTENSI DI PSTW JEMBER
}

\section{(THE EFFECT OF DRY CUPPING THERAPY ON BLOOD PRESSURE IN THE ELDERLY WITH HYPERTENSION AT PSTW JEMBER)}

\author{
Yogie Bagus Pratama ${ }^{1 *}$, Hanny Rasni ${ }^{2}$, Wantiyah ${ }^{3}$ \\ ${ }^{1,2,3}$ Fakultas Keperawatan Universitas Jember \\ Jl. Kalimantan No. 37 Kampus Tegal Boto Jember. Telp./Fax. (0331) 323450 \\ *e-mail: yogiebaguspratama1995@gmail.com
}

\begin{abstract}
ABSTRAK
Lansia ditandai dengan penurunan fungsi tubuh, sehingga menjadikan lansia beresiko tinggi terjadi hipertensi. Hipertensi adalah kondisi peningkatan tekanan darah secara konsisten pada $\geq 140$ / $90 \mathrm{mmHg}$. Pengobatan hipertensi dapat dilakukan secara farmakologi \& nonfarmakologi. Salah satu terapi nonfarmakologi yang dapat digunakan untuk penanganan hipertensi adalah dengan menggunakan terapi bekam kering. Tujuan dari penelitian ini adalah untuk menganalisis pengaruh bekam kering terhadarp tekanan darah lansia dengan hipertensi. Tekanan darah lansia sebagai variabel dependen dan bekam kering sebagai variabel independen. Penelitian ini menggunakan quasi eksperimental dengan two group pre-posttest design. Sampel berjumlah 22 orang yang didapatkan secara simple random sampling. Sampel dibagi dalam dua grup. Analisis data menggunakan Wilcoxon test dan Mann-Whitney test dengan $95 \%$ CI $(\alpha: 0,05)$. Hasil analisis menunjukkan terdapat perbedaan yang signifikan antara pretest dan posttest pada kelompok intervensi ( $\mathrm{p}$ 0,004 sistolik, 0,046 diastolik) dan tidak terdapat perbedaan yang signifikan pada kelompok kontrol ( $\mathrm{p}$ 0,705 sistolik, 0,317 diastolik). Analisis data menunjukkan terdapat perbedaan signifikan antara kelompok intervensi dan kontrol pada sistolik ( $\mathrm{p} 0,007)$, tetapi tidak terdapat perbedaan signifikan pada diastolik $(\mathrm{p}, 0,4)$. Kesimpulan dari penelitian ini adalah terapi bekam kering berpengaruh dalam menurunkan tekanan darah sistol pada lansia dengan hipertensi.
\end{abstract}

Kata kunci: terapi bekam kering, lansia, hipertensi.

\section{ABSTRACT}

Elderly characterized by decreased of body function are in high risk of hypertension. Hypertension is a consistent increase in blood pressure at $\geq 140 / 90 \mathrm{mmHg}$. Treatment of hypertension can be done for both, pharmacologically and nonpharmacologically. One of nonpharmacology therapies to treat hypertension is by using dry cupping therapy. The purpose of this study was to analyze the effect of dry cupping to elderly blood pressure with hypertension. Elderly blood pressure with hypertension as dependent variabel and dry cupping therapy as independent variabel. This research used quasi experimental with two group pre-post test design. The sample was 22 people obtained with simple random sampling. The samples divided into two groups. Data analysis using Wilcoxon test and Mann-Whitney test with 95\% CI ( $\alpha: 0.05)$. Analysis result showed significant differences between pretest and posttest in intervention group (p 0.004 systole, 0.046 diastole) and no significant difference in control group ( $p 0.705$ systole, 0.317 diastole). Data analysis results showed significant differences between intervention and control groups in systole ( $p$ 0.007), but no significant difference in diastole ( $p$ 0.4). Therefore, the conclusion is dry cupping have an effect in decreasing sistol blood pressure in elderly with hypertension.

Keywords: Dry Cupping Therapy, elderly, hypertension 


\section{PENDAHULUAN}

Usia harapan hidup beberapa dekade terakhir mengalami peningkatan, sehingga menyebabkan jumlah lansia semakin meningkat. Usia lanjut ditandai dengan penurunan fungsi tubuh dalam beradaptasi. Penurunan tersebut menyebabkan lansia rawan terserang penyakit kronis seperti hipertensi, asam urat, stroke, gagal ginjal dan jantung. Tekanan darah 160/90 mmHg dapat diklasifikasikan sebagai hipertensi untuk semua batasan usia.

Hasil studi pendahuluan diperoleh data lansia di PSTW Jember berjumlah 140 orang. Lansia yang tercatat mengalami hipertensi pada oktober 2017 sebanyak 50 orang dengan 7 diantaranya mengalami stroke. Penatalaksanaan hipertensi di PSTW Jember berupa pemeriksaan tekanan darah, pemberian obat antihipertensi serta senam lansia secara rutin dua minggu sekali.

Penatalaksanaan hipertensi dapat dilakukan dengan cara farmakologi dan nonfarmakologi. Bekam merupakan jenis pengobatan nonfarmakologi yang cukup dikenal dimasyarakat. Bekam adalah terjemahan dari bahasa arab hijamah yang berarti penyedotan, sehingga dapat didefinisikan sebagai teknik penyedotan dengan alat bekam, baik disertai pengeluaran darah maupun tidak. Bekam tanpa mengeluarkan darah disebut bekam kering. Tujuan penelitian ini adalah untuk menganalisis pengaruh terapi bekam kering terhadap tekanan darah pada lansia dengan hipertensi di PSTW Jember.

\section{METODE}

Penelitian ini menggunakan
metode quasy experiment dengan rancangan two group pre-post test design. Teknik pengambilan sampel adalah probability sampling dengan pendekatan simple random sampling dengan total responden berjumlah 22 orang yang terbagi dalam kelompok kontrol dan intervensi.
Intervensi bekam kering dilakukan sekali waktu dengan rentang waktu 15-30 menit untuk semua responden pada kelompok intervensi. Pengukuran pretest dan posttest pada kelompok intervensi dilakukan 5 menit sebelum dan 5 menit setelah dilakukan terapi bekam kering. Pada kelompok kontrol dilakukan pengukuran pretest dan posttest dengan jarak waktu 30 menit. Penelitian ini dilakukan di Panti Sosial Tresna Werdha (PSTW) Jember.

Analisis data menggunakan analisis univariat dan bivariat. Analisis univariat digunakan untuk menggambarkan karakteristik responden. Analisis bivariat menggunakan uji Wilcoxon dan Mannwhitney dengan $\alpha=0,05$. Peneliti menggunakan program komputer untuk proses pengolahan data dan analisis statistik.

\section{HASIL}

\section{Karakteristik Responden}

Tabel 1. Distribusi Responden berdasarkan Usia Lansia

\begin{tabular}{lccc}
\hline Kelompok & $\begin{array}{c}\text { Mean } \\
\text { (tahun) }\end{array}$ & SD & $95 \%$ CI \\
\hline Intervensi & 73,18 & 7,01 & $68,47-$ \\
Kontrol & 69,09 & 3,01 & 77,89 \\
& & & $67,06-$ \\
& & & 71,11
\end{tabular}

Tabel 1 menunjukkan bahwa ratarata usia responden pada kelompok intervensi adalah 73,18, dan hasil interval kepercayaan $95 \%$ diyakini usia berada pada rentang 68,47-77,89 tahun. Kelompok kontrol memiliki nilai rata-rata usia 69,09 dan hasil interval kepercayaan 95\% diyakini usia berada pada rentang 67,06-71,11 tahun.

Tabel 2. Distribusi Responden berdasarkan Jenis Kelamin dan Riwayat Merokok Lansia 


\begin{tabular}{lcccc}
\hline \multirow{2}{*}{ Karakteristik } & \multicolumn{2}{c}{ Intervensi } & \multicolumn{2}{c}{ Kontrol } \\
\cline { 2 - 5 } & $\mathrm{n}$ & $\%$ & $\mathrm{n}$ & $\%$ \\
\hline a. Jenis Kelamin & & & & \\
- Laki-laki & 8 & 72,7 & 7 & 63,6 \\
- Perempuan & 3 & 23,3 & 4 & 36,4 \\
\hline Total & 11 & 100,0 & 11 & 100,0 \\
\hline b. Riwayat & & & & \\
Merokok & 6 & 54,5 & 6 & 54,5 \\
- Iya & 5 & 45,5 & 5 & 45,5 \\
- Tidak & & & &
\end{tabular}

Tabel 2 jenis kelamin lebih banyak pada laki-laki dengan jumlah total sebanyak 15 orang atau sebesar $68,2 \%$. Sebagian besar responden memiliki riwayat merokok yang berjumlah 12 orang atau sebesar $54,5 \%$.

\section{Tekanan Darah Kelompok Intervensi}

Tabel 3. Gambaran Hasil Pretest dan Posttest Tekanan Darah Lansia

\begin{tabular}{|c|c|c|c|}
\hline $\begin{array}{c}\text { Kelomp } \\
\text { ok } \\
\text { Interve } \\
\text { nsi } \\
\end{array}$ & TD & $\begin{array}{c}\text { Media } \\
\text { n } \\
(\mathbf{m m H} \\
\mathrm{g}) \\
\end{array}$ & $\begin{array}{c}\text { Min- } \\
\text { Max } \\
(\mathbf{m m H} \\
\text { g) }\end{array}$ \\
\hline Pretest & $\begin{array}{c}\text { Sistolik } \\
\text { Diastolik }\end{array}$ & $\begin{array}{c}140 \\
80\end{array}$ & $\begin{array}{c}140- \\
150 \\
70-90\end{array}$ \\
\hline Posttest & $\begin{array}{c}\text { Sistolik } \\
\text { Diastolik }\end{array}$ & $\begin{array}{c}140 \\
80\end{array}$ & $\begin{array}{c}120- \\
150 \\
70-90\end{array}$ \\
\hline
\end{tabular}

Tabel 3 menunjukkan gambaran hasil tekkanan darah pada kelompok intervensi dan didapatkan nilai median $140 / 80 \mathrm{mmHg}$ pada pretest dan posttest. Pada pretest memiliki nilai min-max 140$150 \mathrm{mmHg}$ pada sistolik dan $70-90 \mathrm{mmHg}$ pada diastolik, sedangkan pada posttest memiliki nilai min-max $120-150 \mathrm{mmHg}$ pada sistolik dan $70-90 \mathrm{mmHg}$ pada diastolik.

Tabel 4. Hasil Uji Wilcoxon Tekanan Darah Lansia Berdasarkan Pretest dan Posttest

\begin{tabular}{cccc}
\hline Kelompok & $\begin{array}{c}\text { Tekanan } \\
\text { Darah }\end{array}$ & $\mathbf{Z}$ & $\mathbf{p}$ \\
\hline & $\begin{array}{c}\text { Sistol pretest } \\
\text { Sistol }\end{array}$ & - & \\
Intervensi & $\begin{array}{c}\text { posttest } \\
\text { Diastol } \\
\text { pretest }\end{array}$ & 2887 & 0,004 \\
& Diastol & 2000 & 0,046 \\
& posttest & & \\
\hline
\end{tabular}

Tabel 4 menunjukkan hasil uji Wilcoxon pada tekanan darah sistol dan diastol kelompok intervensi memiliki nilai $\mathrm{p}<0,05$, yaitu 0,004 pada sistolik dan 0,046 pada diastolik.

Hal tersebut menunjukkan bahwa terdapat perbedaan signifikan rata-rata tekanan darah pretest dan posttest pada kelompok intervensi.

\section{Tekanan Darah Kelompok Kontrol}

Tabel 5. Gambaran Hasil Pretest dan Posttest Tekanan Darah Lansia

\begin{tabular}{|c|c|c|c|}
\hline $\begin{array}{l}\text { Kelomp } \\
\text { ok } \\
\text { Kontrol }\end{array}$ & TD & $\begin{array}{c}\text { Media } \\
\text { n } \\
(\mathbf{m m H} \\
\mathbf{g}) \\
\end{array}$ & $\begin{array}{c}\text { Min- } \\
\text { Max } \\
(\mathbf{m m H} \\
\text { g) }\end{array}$ \\
\hline Pretest & $\begin{array}{c}\text { Sistolik } \\
\text { Diastolik }\end{array}$ & $\begin{array}{c}140 \\
80\end{array}$ & $\begin{array}{c}140- \\
155 \\
70-90\end{array}$ \\
\hline Posttest & $\begin{array}{c}\text { Sistolik } \\
\text { Diastolik }\end{array}$ & $\begin{array}{c}145 \\
80\end{array}$ & $\begin{array}{c}140- \\
150 \\
70-90\end{array}$ \\
\hline
\end{tabular}

Tabel 5 menunjukkan gambaran hasil tekkanan darah pada kelompok kontrol dan didapatkan nilai median $140 / 80 \mathrm{mmHg}$ pada pretest dan $145 / 80 \mathrm{mmHg}$ pada posttest. Pada pretest memiliki nilai min-max $140-155 \mathrm{mmHg}$ pada sistolik dan $70-90 \mathrm{mmHg}$ pada diastolik, sedangkan pada posttest memiliki nilai min-max $140-150 \mathrm{mmHg}$ pada sistolik dan $70-90 \mathrm{mmHg}$ pada diastolik.

Tabel 6. Hasil Uji Wilcoxon Tekanan 
Darah Lansia Berdasarkan Pretest dan Posttest

\begin{tabular}{lccc}
\hline Kelompok & $\begin{array}{c}\text { Tekanan } \\
\text { Darah }\end{array}$ & $\mathbf{Z}$ & $\mathbf{p}$ \\
\hline & $\begin{array}{c}\text { Sistol } \\
\text { pretest } \\
\text { Sistol }\end{array}$ & & \\
Kontrol & posttest & -378 & 0,705 \\
& $\begin{array}{c}\text { Diastol } \\
\text { pretest }\end{array}$ & -1000 & 0,317 \\
& Diastol & & \\
posttest & & \\
\hline
\end{tabular}

Tabel 6 menunjukkan hasil uji Wilcoxon pada tekanan darah sistol dan diastol kelompok kontrol memiliki nilai p >0,05, yaitu 0,705 pada sistolik dan 0,317 pada diastolik.

Hal tersebut menunjukkan bahwa tidak terdapat perbedaan signifikan ratarata tekanan darah pretest dan posttest pada kelompok kontrol.

\section{Tekanan Darah Kelompok Intervensi dan Kelompok Kontrol}

Tabel 7. Hasil Uji Mann Whitney Tekanan Darah Sistolik Lansia pada Kelompok Intervensi dan Kelompok Kontrol

\begin{tabular}{lccc}
\hline Kelompok & $\begin{array}{c}\text { Tekanan } \\
\text { Darah }\end{array}$ & $\mathbf{Z}$ & $\mathbf{p}$ \\
\hline $\begin{array}{l}\text { Intervensi } \\
\text { Kontrol }\end{array}$ & Sistol & $\begin{array}{c}- \\
\text { Intervensi }\end{array}$ & 0,007 \\
\hline $\begin{array}{l}\text { Kontrol } \\
\text { Diastol }\end{array}$ & -841 & 0,400 \\
\hline
\end{tabular}

Tabel 7 menunjukkan hasil uji Mann-Whitney perbedaan rata-rata tekanan darah lansia antara kelompok intervensi dan kelompok kontrol di UPT PSTW Jember setelah diberikan terapi bekam kering mendapatkan $p$ value $=0,007$ pada sistolik dan 0,4 pada diastolik.

Hal tersebut menunjukkan bahwa terdapat perbedaan signifikan rata-rata tekanan darah sistol antara kelompok intervensi dan kelompok kontrol, serta tidak terdapat perbedaan signifikan rata- rata tekanan darah diastol antara kelompok intervensi dan kelompok kontrol

\section{PEMBAHASAN \\ Karakteristik Responden}

Rata-rata usia yang menjadi responden dalam penelitian adalah 73,18 tahun pada kelompok intervensi dan 69,09 tahun pada kelompok kontrol. Prevalensi hipertensi berbanding lurus dengan peningkatan usia, semakin tua usia maka semakin banyak juga kejadian hipertensi. Kejadian hipertensi semakin meningkat dengan bertambahnya usia. Hal ini didukung dari hasil penelitian yang menyebutkan bahwa prevalensi hipertensi lebih tinggi pada usia 75-90 tahun yaitu sebanyak $64 \%$ dibandingkan pada usia 6074 tahun yaitu sebanyak $36 \%$. Peningkatan usia menyebabkan terjadinya penebalan pada ventrikel kiri dan katub jantung, menurunnya pacemaker jantung, terjadi kekakuan pembuluh darah arteri dan katub vena menjadi tidak kompeten yang semuanya itu secara progresif meningkatkan tekanan darah dan beresiko terjadinya hipertensi.

Mayoritas responden penelitian berjenis kelamin laki-laki 15 (68,2\%). Laki-laki diduga memiliki gaya hidup lebih cenderung untuk meningkatkan tekanan darah seperti merokok, stres akibat beban hidup dsb. Hasil penelitian sebelumnya menyebutkan bahwa hipertensi lebih banyak terjadi pada lakilaki.

Sebagian besar responden penelitian memiliki riwayat merokok 12 (54,4\%). Penelitian sebelumnya menyebutkan bahwa terdapat hubungan signifikan antara perilaku merokok dengan kejadian hipertensi dengan nilai p 0,001.

Nikotin yang terkandung dalam rokok dapat mempengaruhi tekanan darah melalui pembentukan plak atersklerosis. Nikotin juga memiliki efek langsung pada pelepasan hormon epinefrin dan nonepinefrin. Karbonmonoksida yang meningkat dalam darah akibat merokok juga dapat mempengaruhi tekanan darah. 
Hasil analisa data dengan menggunakan uji Wilcoxon pada kelompok kontrol, terdapat penurunan rata-rata

\section{Perbedaan Tekanan Darah Kelompok Intervensi}

Hasil analisa data dengan menggunakan uji Wilcoxon pada kelompok intervensi, terdapat penurunan rata-rata tekanan darah sebesar 9,09 pada sistolik dan 3,63 pada diastolik dengan nilai $\mathrm{p}$ 0,004 pada sistolik dan 0,046 pada diastolik $(p<\alpha)$. Berdasarkan hasil analisa tersebut dapat disimpulkan bahwa terdapat perbedaan signifikan rata-rata tekanan darah sebelum dan setelah diberikan terapi bekam kering pada kelompok intervensi.

Hasil penelitian ini sejalan dengan hasil penelitian Irawan dan Ari tentang pengaruh terapi bekam terhadap penurunan tekanan darah pada klien hipertensi yang menyatakan bahwa tekanan darah sistol dan diastol mengalami penurunan rata-rata sebesar $22,87 \mathrm{mmHg}$ pada sistol dan $21,42 \mathrm{mmHg}$ pada diastol. Secara teori tekanan darah dipengaruhi oleh tiga hal, yaitu kecepatan denyut jantung, cardiac output, dan Total Resistance Peripheral (TPR). Pembekaman pada kulit dapat menyebabkan terjadinya kerusakan pada Mast Cell. Akibat kerusakan ini akan dilepaskannya beberapa zat seperti serotonin, histamin, bradikinin, slow reacting substance (SRS), serta zat lain yang belum diketahui. Zat-zat ini menyebabkan terjadinya dilatasi kapiler dan arteriol, tidak hanya disekitar tempat bekam melainkan juga ditempat yang jauh dari titik bekam, sehingga terjadi perbaikan mikrosirkulasi pembuluh darah. Menurut Widada, bekam memiliki efek rileksasi otot. Rileksasi tersebut diakibatkan oleh produksi hormon endorfin pada saat dilakukan bekam. Pada saat tubuh merasa nyaman, frekuensi jantung akan mengalami penurunan.

\section{Perbedaan Tekanan Darah Kelompok Kontrol} tekanan darah sebesar 0,46 pada sistolik dan 1,82 pada diastolik dengan nilai $p$ 0,705 pada sistolik dan 0,317 pada diastolik $(p<\alpha)$. Berdasarkan hasil analisa tersebut dapat disimpulkan bahwa tidak terdapat perbedaan signifikan rata-rata tekanan darah sebelum dan setelah diberikan terapi bekam kering pada kelompok intervensi. Meskipun terdapat penurunan rata-rata tekanan darah pada kelompok kontrol, akan tetapi secara statistik penurunan yangterjadi tidak signifikan, hal ini dikarenakan tidak diberikannya terapi bekam kering pada kelompok kontrol selama penelitian..

Terdapat beberapa faktor yang dapat mempengaruhi tekanan darah yang meliputi riwayat keluarga, aktifitas fisik, merokok, konsumsi alkohol, stres, obesitas, diet natrium dan diabetes. Penurunan tekanan darah yang terjadi pada kelompok kontrol dipengaruhi oleh faktor-faktor lain yang mempengaruhi tekanan darah, karena pada kelompok kontrol tidak diberikan terapi bekam. Faktor-faktor lain yang mempengaruhi tekanan darah lansia di PSTW meliputi diet natrium, aktifitas fisik rutin berupa senam lansia, serta kajian rohani rutin setiap minggu. Selain itu, pengobatan rutin yang diberikan tenaga kesehatan untuk mengatasi hipertensi pada lansia juga memliki peranan dalam menurunkan tekanan darah pada kelompok kontrol.

\section{Pengaruh Relaksasi Aromaterapi Jasmine terhadap Kualitas Tidur pada Lansia di Karang Werdha Kecamatan Jenggawah Kabupaten Jember}

Hasil analisa data menggunakan uji Mann-Whitney terhadap perbedaan tekanan darah antara kelompok kontrol dan intervensi didapatkan nilai $p 0,007$ pada tekanan darah sistolik dan $\mathrm{p} 0,4$ pada tekanan darah diastolik. Berdasarkan hasil analisis tersebut menunjukkan bahwa terdapat perbedaan signifikan rata-rata 
tekanan darah sistolik antara kelompok intervensi dan kelompok kontrol, akan tetapi pada tekanan darah diastol tidak terdapat perbedaan yang signifikan ratarata tekanan darah antara kelompok kontrol dan perlakuan. Oleh karena itu dapat disimpulkan bahwa, bekam kering berpengaruh terhadap penurunan tekanan darah sistol pada lansia dengan hipertensi di PSTW Jember.

Menurut Umar, bekam menyebabkan reaksi peradangan yang dapat mengakibatkan terlepasnya zat serotonin, histamin, bradikinin, slow reacting substance (SRS), serta zat lain yang belum diketahui. Zat-zat tersebut menyebabkan terjadinya dilatasi kapiler dan arteriol. Bekam menstimulasi untuk diproduksinya zat nitric oxide (NO) yang berdampak pada relaksasi otot polos pembuluh darah. Pengeluaran zat-zat tersebut menyebabkan vasodilatasi dan relaksasi pembuluh darah, yang mana hal ini akan berdampak pada penurunan tekanan darah. Tekanan negatif efek dari bekam menyebabkan terjadinya dilatasi kapiler. Pembekaman juga menghasilkan heme oxygenase-1 (HO-1) yang berfungsi untuk memetabolisme heme. Katalisis heme menghasilkan karbon monoksida (CO). Produksi $\mathrm{CO}$ dari aktivasi heme oxygenase-1 (HO-1) menstimulasi diproduksinya cyclic guanosine monophosphate (cGMP) yang berfungsi untuk vasodilatasi pembuluh darah, meskipun efeknya sedikit lemah jika dibandingkan dengan nitric oxide (NO).

Menurut hasil penelitian yang dilakukan oleh Rusdiatin, respon dari seseorang setelah dilakukan bekam menyatakan merasa nyaman dan timbul rasa kantuk. Pada saat seseorang merasa nyaman dan relaks, maka sistem saraf simpatik akan tenang dan yang lebih banyak berperan adalah sistem saraf parasimpatik. Kondisi relaks menyebabkan frekuensi jantung menurun, dengan menurunnya frekuensi jantung, maka tekanan darah juga akan menurun.
Berdasarkan hasil penelitian, peneliti menunjukkan bahwa bekam kering telah memberikan manfaat yang nyata dalam menurunkan tekanan darah pada lansia dengan hipertensi. Bekam menyebabkan dilatasi pembuluh darah, penurunan denyut jantung serta perbaikan elastisitas pembuluh darah yang kesemuanya secara teori memiliki pengaruh dalam menurunkan tekanan darah. Penelitian ini diperkuat oleh teoriteori yang sudah dikemukakan serta faktafakta terkait hasil analisa data pada uji Mann-Whitney yang mendapatkan nilai $\mathrm{p}$ 0,004 pada teanan darah sistol $(\mathrm{p}<0,05)$. Oleh karena itu, peneliti menyimpulkan bahwa terapi bekam kering memiliki pengaruh dalam menurunkan tekanan darah sistol pada lansia dengan hipertensi di PSTW Jember.

\section{KESIMPULAN}

Terjadi penurunan rata-rata tekanan darah pada lansia dengan hipertensi setelah diberikan terapi bekam kering, hal ini menunjukkan bahwa bekam kering memiliki efek yang baik terhadap tekanan darah lansia dengan hipertensi. Terdapat perbedaan yang signifikan rata-rata tekanan darah sistol antara kelompok intervensi dan kelompok kontrol, akan tetapi pada tekanan darah diastol tidak terdapat perbedaan yang signifikan ratarata tekanan darah antara kelompok intervensi dan kelompok kontrol. Dengan demikian dapat disimpulkan bahwa bekam kering memiliki pengaruh dalam menurunkan tekanan darah sistol pada lansia dengan hipertensi.

\section{SARAN}

Penelitian ini diharapkan dapat menjadi tambahan informasi mengenai terapi komplementer, khususnya pada terapi bekam kering, sehingga diharapkan dapat diaplikasikan dalam pemberian asuhan keperawatan baik ditatanan klinik maupun komunitas.

Penelitian ini dapat menjadi acuan untuk penelitian selanjutnya, diharapkan 
dapat mengontrol faktor-faktor yang dapat menyebabkan bias. Selain itu, penelitian selanjutnya juga dapat melakukan bekam kering pada variabel yang lain seperti nyeri, stress, gangguan tidur dsb yang secara teori memiliki keterkaitan satu sama lain

\section{UCAPAN TERIMA KASIH}

Peneliti menyampaikan terima kasih kepada responden penelitian dan PSTW Jember yang telah memberikan ijin dan bersedia menjadi responden penelitian.

\section{KEPUSTAKAAN}

Badan Pusat Statistik. 2014. Statistik penduduk lansia. Jakarta: BPS Jakarta-Indonesia; 2015

Efendi, F. \& Mahfudli. 2009. Keperawatan kesehatan komunitas: teori dan praktik dalam keperawatan. Jakarta:Salemba Medika;

Sunaryo, Wijayanti, M., Kuhu, M., Sumedi, T., Widayanti, ED., Sukrillah, UA., Riyadi, S., \& Kuswanti, A. 2015. Asuhan keperawatan gerontik. Yogyakarta: CV ANDI OFFSET;

Baradero, M., Wilfrid, D., \& Yakobus. S. 2008. Klien gangguan kardiovaskuler. Jakarta: Penerbit Buku Kedokteran EGC;

Tao L, Kendall. 2014. Sinopsis organ kardiovaskuler: pendekatan dengan sistem terpadu dan disertai kumpulan kasus klinik. Tanggerang Selatan: KARISMA Publishing Group;

Sugung I. 2017. Hidup sehat dengan detoks. Yogyakarta: Khitah Publishing;

Aldjoefrie MR. 2015 . Bekam hijamah menurut sains dan kedokteran modern [internet]. [cited 2 Juni 2018]. Availeble from: https://books.google.co.id/books?id $=\mathrm{j} \operatorname{KozBgAAQBAJ} \&$ printsec $=$ front cover\&dq=bekam+hijamah+menur ut+sains+dan+kedokteran+modern $\underline{\text { \&hl=en\&sa }=\text { X\&ved=0ahUKEwjqy }}$ Yaxr4DcAhVUfH0KHf_-
BHoQ6wEIKjAA\#v=onepage \&q= bekam\%20hijamah\%20menurut $\% 2$ 0sains\%20dan\%20kedokteran\%20 modern \&f=false

Buford TW. 2016 Hypertension and aging. Ageing Research Reviews [internet]. [cited 29 Januari 2018]: 96-111. Available from: http://dx.doi.org/10.1016/j.arr.2016 .01 .007

Badan Litbangkes. 2013. Riset kesehatan dasar 2013. Jakarta: Badan Litbangkes Kemenkes RI;

Seke PA, Bidjuni HJ, Lolong J. 2016. Hubungan kejadian stres dengan penyakit hipertensi pada lansia di balai penyantunan lanjut usia senjah cerah kecamatan mapanget kota manado. E-Journal Keperawatan.; 4(2): 1-5

Stanley M, Beare PG. 2006. Gerontological nursing: a health promotion/protection approach $2^{\text {nd }}$ edition. Philadelphia: The F.A. Davis Company;

Purnama DS, Prihartono NA. 2013. Prevalensi hipertensi dan faktorfaktor yang berhubungandengan kejadian hipertensi pada lansia di posyandu lansia wilayah kecamatan johar baru. Jakarta Pusat: FKM UI;

Mohan V, Deepa M, Farooq S, Datta M, Deepa R. 2007 . Prevalence, awareness and control of hypertension in Chennai-The Chennai Urban Rural Epidemiology Study (CURES-52). J Assoc Physicans India [internet]. [cited 03 Desember 2017] Available from: https://www.ncbi.nlm.nih.gov/pub med/17844691

Retnaningsih D, Kustriyani M, Sanjaya BT. 2017. Perilaku merokok dengan kejadian hipertensi pada lansia. Semarang: Stikes Widya Husada Semarang;

Setyanda YOG, Sulastri D, Lestari Y. 2015. Hubungan merokok dengan 
kejadian hipertensi pada laki-laki usia 35-65 tahun di kota padang. Jurnal Kesehatan Andalas.; 4(2): 434-440

Irawan H, Ari S. 2012. Pengaruh terapi bekam terhadap penurunan tekanan darah pada klien hipertensi. Jurnal Ilmu Kesehatan.; 1(1):31-37

Corwin E. 2009. Buku saku patofisiologi edisi 3.Jakarta: Penerbit Buku Kedokteran EGC;

Widada W. 2011. Terapi bekam sebagai solusi cerdas mengatasi radikal bebas akibat rokok: berdasarkan penelitian terbaru terhadap komponen Darah. Bandung: Lubuk Agung;

Rusdiatin IE. 2015. Terapi bekam kering terhadap penurunan tekanan darah pada lansia dengan hipertensi. Jurnal Kesehatan Madani.; 6(2): 92-98

Potter PA, Perry AG. 2005. Fundamental of nursing: concepts, process, and practice volume $14^{\text {th }}$ edition. Saint Louis: Mosby - Year Book Inc;

Bell K, Twiggs J, Olin BR. 2015. Hypertension:the silent killer: update JNC-8 guideline recommendations. Contuining Education [internet]. [cited 24 Februari 2018] Available from:https://c.ymcdn.com/sites/ww w.aparx.org/resource/resmgr/CEs/C E_Hypertension_The_Silent_K.pdf

Umar WA. 2008. Sembuh dengan satu titik. Solo: A-Qowam Publishing;

Lowe DT. 2017 . Cupping therapy: an analysis of the effects of suction on skin and the possible influence on human health, complementary therapies in clinical practice [internet]. [cited 25 Februari 2018]. Available from: http://dx.doi.org/10.1016/j.ctcp.201 7.09.008

Ramdhani N, Putra AA. 2008. Pengembangan multimedia relaksasi.Yogyakarta: Bagian Psikologis Klinis Fakultas
Psikologi UGM [internet]. [cited 18 Desember 2017]. Available from: http://Neila.staff.ugm.ac.id/wordpr ess/wp-content/upload. 